\title{
FAKTOR PENDORONG TERKAIT PERILAKU PATUH KARYAWAN PT PUPUK KALIMANTAN TIMUR DALAM MENGGUNAKAN ALAT PELINDUNG TELINGA (APT)
}

\section{DRIVING FACTORS RELATED TO COMPLIANCE BEHAVIOR AMONG \\ PT. PUPUK KALIMANTAN TIMUR EMPLOYEES IN USING THE EAR PROTECTIVE EQUIPMEN}

\author{
Rudi Arifin1), Meirina Ernawati1), Teddy Zulfikar Rachman²)
}

\begin{abstract}
${ }^{1}$ Fakultas Kesehatan Masyarakat, Universitas Airlangga, Surabaya
2Departeman Keselamatan dan Kesehatan Kerja, PT. Pupuk Kalimantan Timur, Bontang

E-mail: rudiarifin012@gmail.com
\end{abstract}

\begin{abstract}
Background: Noise has an impact on hearing loss and decreased power. Therefore the need for noise control one of them by using the ear protector. However, some studies have been done that workers who do not use personal protective equipment as the highest risk compared with others. It is necessary to change the behavior of workers who do not use personal protective equipment to be obedient in using personal protective equipment. Purpose: the aims of this study to identify several factors that encourage obedient behavior toward the use of ear protector in PT. Pupuk Kalimantan Timur. Methods: This research method using descriptive research by using Primary and secondary data. Primary data collected from indepth interview and observation. Results: The results of the study explained that all operators of ammonia and urea compressors of PT. Pupuk Kalimantan Timur Already Compliant in using ear protection. However, there are still a number of factors that are less appropriate. The driving factors are knowledge of noise engineering control, direct impact of noise, intensity and duration of exposure. Conclusion: The driving factors are knowledge of noise engineering control, direct impact of noise, intensity and duration of exposure.
\end{abstract}

Keywords: ear protector, predisposing factor, reinforcing factor, enabling factor, Operator of ammonia and urea Compressor, Behavior

\begin{abstract}
ABSTRAK
Latar Belakang: Kebisingan memiliki dampak terhadap gangguan pendengaran dan penurunan daya kerja, oleh karena itu perlunya pengendalian kebisingan salah satunya dengan cara menggunakan Alat Pelindung Telinga (APT). Beberapa penelitian yang pernah dilakukan menyebutkan bahwa pekerja yang tidak menggunakan Alat Pelindung Diri (APD) sebagai risiko tertinggi dibandingkan dengan yang lain, maka diperlukan perubahan perilaku pekerja yang tidak menggunakan APD menjadi patuh dalam menggunakan APD. Tujuan: tujuan penelitian untuk mengidentifikasi beberapa faktor pendorong perilaku patuh terhadap penggunaan APT di PT. Pupuk Kalimantan Timur. Metode: Metode penelitian ini menggunakan penelitian deskriptif dengan menggunakan data Primer dan sekunder. Data primer diperoleh dari wawancara mendalam dan observasi. Hasil: Hasil penelitian menjelaskan bahwa seluruh operator kompresor ammonia dan urea PT. Pupuk Kalimantan Timur Sudah Patuh dalam menggunakan APT, namun masih terdapat beberapa faktor pendorong yang kurang sesuai. Faktor pendorong tersebut adalah pengetahuan tentang pengendalian teknik dari kebisingan, dampak langsung dari kebisingan, intensitas dan durasi paparan. Kesimpulan: faktor pendorong ketidakpatuhan adalah pengetahuan operator kompresor tentang pengendalian
\end{abstract}


kebisingan secara teknik, dampak langsung dari kebisingan, intensitas dan durasi paparan yang sesuai.

Kata Kunci: Alat Pelindung Telinga (APT), faktor predisposisi, faktor penguat, faktor pemungkin, operator kompresor ammonia dan urea, perilaku.

\section{PENDAHULUAN}

Mayoritas industri besar dalam pemenuhan proses produksi pasti menggunakan peralatan atau mesin yang berkapasitas besar. Peralatan tersebut dalam proses kerjanya akan menimbulkan keluaran negatif yang dapat membahayakan manusia. Keluaran negatif tersebut diantaranya suhu panas, getaran, dan kebisingan. Semakin besar mesin produksi tentunya akan menghasilkan keluaran negatif yang besar, oleh karena itu pada mesin atau peralatan produksi yang besar mengeluarkan keluaran negatif yang dapat melebihi nilai ambang batas.

Keluaran negatif yang ditimbulkan oleh mesin atau peralatan industri salah satunya adalah kebisingan. Menurut Suma'mur (2009) kebisingan dapat mempengaruhi kesehatan dan daya kerja. Kebisingan yang mengganggu kesehatan manusia yaitu pada indra pendengaran manusia secara permanen dan kebisingan dapat menyebabkan gangguan daya kerja yaitu menurunkan konsentrasi, melemahkan motivasi untuk bekerja, dan mengganggu proses komunikasi.

Penelitian yang dilakukan Setyanto dkk (2011) memperoleh hasil bahwa pekerja yang terpapar kebisingan dengan intensitas $50 \mathrm{dBA}$ dapat menyelesaikan pekerjaanya dalam waktu 5,88 detik, sedangkan pada pekerja yang terpapar kebisingan dengan intensitas $95 \mathrm{dBA}$ dapat menyelesaikan pekerjaan selama 7,19 detik. Hal tersebut dapat disimpulkan bahwa kebisingan dapat mempengaruhi waktu penyelesaian pekerjaan.

Penelitian yang dilakukan Tjan dkk (2013) memperoleh hasil bahwa pekerja terpapar kebisingan dengan intensitas kebisingan sebesar 80-97 dBA, sementara itu hasil pemeriksaan nilai ambang dengar diperoleh hasil sebanyak 1 orang mengalami tuli berat, 2 orang mengalami tuli sedang, 12 orang mengalami tuli ringan dan 5 orang dengan ambang pendengaran normal. Penelitian tersebut mendapatkan hasil bahwa terdapat korelasi antara intensitas kebisingan dengan gangguan fungsi pendengaran.

Beberapa penelitian tersebut, kebisingan menjadi sumber bahaya yang dapat mengganggu kesehatan dan daya kerja seseorang. Berdasarkan dampak kebisingan tersebut Tarwaka (2004) menjelaskan hierarki mengenai pengendalian kebisingan diantaranya eliminasi, substitusi, pengendalian teknik, pengendalian administratif, dan penggunaan APD.

Penelitian yang dilakukan Rahmawati (2015) pada 66 orang pekerja bagian Metal Forming and Heat Treatment PT. Dirgantara Indonesia. Penelitian tersebut menjelaskan bahwa terdapat hubungan yang signifikan antara penggunaan APT, riwayat merokok dan hobi terkait bising dengan gangguan pendengaran.

Penelitian yang dilakukan oleh Prakoso (2017) memperoleh hasil bahwa beberapa faktor kecelakaan kerja pada PT. ABCD antara lain APD (23\%), berkendara $(4 \%)$, posisi tubuh $(1,5 \%)$, dan area kerja $(0,6 \%)$. Berdasarkan persentase tersebut, APD menjadi faktor kecelakaan kerja terbesar dibandingkan dengan faktor kecelakaan yang lain. Penelitian tersebut juga menerangkan bahwa pekerja yang tidak memakai APD menganggap hal ini tidak perlu karena sudah kebiasaan tidak memakai, sehingga perlunya peningkatan kepatuhan penggunaan APT dengan melakukan perubahan perilaku dalam menggunakan APT. Perubahan perilaku tersebut untuk mengurangi risiko terjadinya penyakit akibat kerja dalam hal ini gangguan pendengaran dan pengurangan daya kerja.

Green dalam Notoatmojo (2007) menjelaskan bahwa terjadinya suatu perilaku dikarenakan 3 faktor pendorong yaitu predisposisi, pemungkin, dan penguat. Hal tersebut menjadi landasan konseptual untuk mengidentifikasi Perilaku patuh terhadap penggunaan APT. Berdasarkan hal tersebut peneliti tertarik untuk mengidentifikasi beberapa faktor pendorong 
perilaku patuh terhadap penggunaan APT di PT. Pupuk Kalimantan Timur.

\section{METODE}

Teknik penelitian yang dilakukan adalah penelitian observasional. Penelitian ini dilakukan untuk mengidentifikasi faktor yang mendorong terjadinya perilaku patuh terhadap penggunaan APT di PT. Pupuk Kalimantan timur. Beberapa faktor pendorong yang diamati yaitu faktor predisposisi terdiri dari Tingkat Pengetahuan, dan komitmen. Peneliti mengategorikan tingkat pengetahuan sesuai pada Tabel 1.

Pengategorian tingkat pengetahuan diketahui dengan melihat persentase operator kompresor dapat menjawab beberapa pertanyaan yang telah disampaikan oleh peneliti.

Tabel 1. Kategori Tingkat Pengetahuan

\begin{tabular}{ccc}
\hline No & $\begin{array}{c}\text { Pertanyaan yang } \\
\text { Diketahui }\end{array}$ & $\begin{array}{c}\text { Kategori } \\
\text { Pengetahuan }\end{array}$ \\
\hline 1. & $1-25 \%$ & Rendah \\
2. & $26-50 \%$ & Sedang \\
3. & $51-75 \%$ & Tinggi \\
4. & $76-100 \%$ & Sangat Tinggi \\
\hline
\end{tabular}

Faktor selanjutnya yaitu faktor pemungkin yang terdiri dari ketersediaan APD, dan papan informasi yang terakhir yaitu faktor penguat yang terdiri dari pengawasan, sosialisasi dan pelatihan, kebijakan, panutan, hukuman, dan penghargaan. Metode yang dilakukan dalam penelitian ini menggunakan penelitian deskriptif.

Penelitian ini menggunakan populasi operator kompresor ammonia dan urea PT. Pupuk Kalimantan Timur. Jumlah populasi operator kompresor ammonia dan urea sebesar 40 orang. Pengumpulan data diperoleh dari data primer dan data sekunder. Data primer diperoleh dari data hasil wawancara mendalam kepada operator kompresor PT Pupuk Kalimantan Timur, selain itu wawancara dilakukan kepada pekerja yang bertanggung jawab atas pengadaan APD dan Pengukuran Kebisingan di area kompresor. Peneliti juga melakukan observasi secara langsung pada operator kompresor PT. Pupuk Kalimantan Timur mengenai perilaku pemakaian APT.
Data sekunder diperoleh dari pekerja Departemen Keselamatan dan Kesehatan Kerja PT. Pupuk Kalimantan Timur berupa data peraturan, kebijakan, dan program yang terkait dengan penelitian.

Wawancara mendalam pada operator kompresor ammonia dan urea untuk mengetahui pengetahuan, komitmen dan perilaku penggunaan APT. Wawancara mendalam pada petugas Keselamatan dan Kesehatan Kerja (K3) untuk mengetahui tentang pengukuran kebisingan, sosialisasi, pelatihan, penyediaan, perawatan, pengawasan, dan pendistribusian APT. Semua data terkumpul, kemudian langkah selanjutnya adalah analisis data. Analisis data dilakukan dengan mengaitkan beberapa faktor pendorong dengan perilaku penggunaan APT.

\section{Karakteristik Operator Kompresor Ammonia dan Urea.}

Operator kompresor ammonia dan urea memiliki karakteristik seperti jenis kelamin, tingkat pendidikan, usia, dan masa kerja. Seluruh operator kompresor memiliki jenis kelamin laki-laki dan memiliki tingkat pendidikan setara SMA. Distribusi usia dan masa kerja operator kompresor ammonia dan urea sebagai berikut:

Tabel 2. Karakteristik Operator Ammonia dan Urea

\begin{tabular}{clcc}
\hline No & Kategori & Jumlah & Prosentase \\
\hline 1 & Usia & & \\
& $20-25$ tahun & 16 & $40 \%$ \\
& $26-30$ tahun & 12 & $30 \%$ \\
& $31-35$ tahun & 2 & $5 \%$ \\
& $36-40$ tahun & 10 & $25 \%$ \\
\hline 2 & Masa Kerja & & \\
& $1-5$ tahun & 7 & $17,5 \%$ \\
& $11-15$ tahun & 3 & $7,5 \%$ \\
& $16-20$ tahun & 7 & $17,5 \%$ \\
\hline
\end{tabular}

Operator kompresor ammonia dan urea paling banyak memiliki usia 20-25 tahun dengan persentase sebesar $40 \%$. Rata-rata usia yang dimiliki oleh operator kompresor sebesar 28,71 \pm 5,84 tahun. Usia paling tinggi yaitu 40 tahun dan paling rendah berusia 23 tahun, selain itu operator kompresor paling banyak bekerja selama 6-10 tahun dengan persentase sebesar $57,5 \%$ dengan rata-rata masa kerja selama 
$9,17 \pm 5,3$ tahun. Masa kerja paling cepat selama 1-5 tahun dan paling lama selama 16-20 tahun.

\section{Deskripsi Pekerjaan Operator Kompresor Ammonia dan Urea.}

Operator kompresor ammonia dan urea bertugas untuk menjaga (memonitor) mesin dan peralatan area kompresor agar tetap berjalan dengan stabil. Monitor tersebut dilakukan selama 2 jam sekali pada saat kondisi mesin normal. Durasi dalam 1 kali monitor atau log sheet rata-rata selama 30 menit. Apabila durasi kerja selama 1 hari 8 jam, maka operator kompresor ammonia dan urea melakukan 4 kali monitor dalam 1 hari. Jadi dalam 1 hari ratarata operator kompresor berada di area kompresor selama 2 jam. Apabila lembur, maka durasi kerja menjadi 2 kali lipat dan durasi monitor juga menjadi 2 kali lipat. Durasi pada area kompresor saat lembur yaitu menjadi 4 jam. Selain itu sisa waktu dihabiskan operator kompresor di tempat istirahat atau shelter. Shelter tersebut berada tidak jauh dari area kompresor yang bertujuan agar tidak membutuhkan jarak tempuh yang lama apabila terjadi masalah pada peralatan dan mesin yang berada di area kompresor.

Saat mesin yang ada pada area kompresor tersebut sedang memulai start awal, operator kompresor ammonia dan urea biasanya lebih lama menghabiskan waktu di area kompresor. Rata-rata mereka berada di area kompresor selama 6 jam. Apabila lembur, durasi tersebut akan menjadi 2 kali lipat yaitu menjadi 12 jam per hari. Hal tersebut sangat berisiko terjadi gangguan pendengaran bagi operator kompresor apabila tidak menggunakan APT. Karena rata-rata tingkat kebisingan di area kompresor yaitu $94 \pm 9$ dBA.

\section{Penggunaan APT}

Menurut hasil wawancara dan observasi yang dilakukan peneliti, sejumlah $100 \%$ operator kompresor ammonia dan urea telah berperilaku patuh dalam menggunakan APT pada area kompresor. Beberapa jenis APT yang digunakan operator kompresor seperti pada gambar 1.Berdasarkan gambar 1, APT yang paling banyak digunakan yaitu ear plug sebesar

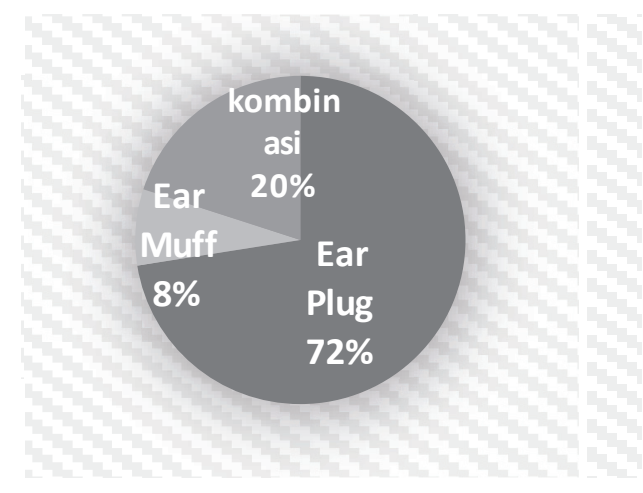

Gambar 1. Penggunaan APT

72\%. Berdasarkan hasil wawancara yang dilakukan, operator kompresor ammonia dan urea yang suka menggunakan ear plug beralasan bahwa ear plug lebih simple sebesar 98\%, dirasa cukup meredam kebisingan sebesar 48\%, lebih nyaman sebesar $76 \%$ dan komunikasi lebih mudah sebesar 84\%. Mereka juga berpendapat tentang kekurangan pada ear muff. Kekurangan yang dirasakan yaitu susah mendengar radio atau HT sebesar $76 \%$, telinga terasa pengap atau vakum sebesar $46 \%$, helm terasa berat sebesar $38 \%$, terasa longgar di telinga atau kurang pas di telinga sebesar 32\% dan bisa menimbulkan lecet pada telinga $24 \%$.

Pendapat lain disampaikan pada operator kompresor yang suka memakai ear muff. Mereka merasa ear muff dapat mengurangi kebisingan lebih tinggi sebesar $89 \%$, mereka merasa lebih aman sebesar $66 \%$, merasa yakin menggunakan ear muff sebesar $96 \%$, dan ear muff terpasang di helm jadi tidak mudah ketinggalan sebesar $48 \%$. Sedangkan ketika mereka memakai ear plug, mereka merasa suara bising masih terdengar jelas sebesar 89\%, mereka kurang yakin dan masih takut mengalami penurunan pendengaran sebesar $96 \%$.

Operator yang memakai kedua APT tersebut menjelaskan bahwa kedua APT tersebut tidak ada yang mengganggu sebesar 100\%, mereka merasa aman memakai keduanya 94\%. Alasan mereka memakai kedua APT dikarenakan kebisingan masih terasa ketika mereka memakai salah satu APT sebesar 100\%, namun masih terdapat kendala pada pemakaian APT secara kombinasi. Kendala tersebut yaitu terganggunya komunikasi pada radio atau HT sebesar $86 \%$. 
Hasil wawancara yang diperoleh, apabila APT operator kompresor ammonia dan urea ketinggalan akan berpengaruh kepada mereka yang biasanya meminta persediaan pada departemen. Apabila persediaan tidak ada, mereka biasanya meminjam APT temanya. Apabila tidak ada langkah terakhir mereka menyumbat telinga mereka dengan kapas, tisu, dan lainnya. Namun kejadian tersebut jarang dialami oleh mereka.

Keberhasilan PT. Pupuk Kalimantan Timur untuk mendorong perilaku operator kompresor ammonia menjadi patuh dalam menggunakan APT pasti ada beberapa faktor pendorong. Faktor pendorong terjadinya perilaku patuh terhadap penggunaan APT apabila dilihat berdasarkan teori Lawrence Green dalam Notoatmojo (2007) sebagai berikut:

\section{Faktor Predisposisi (Predisposing Factor)}

Faktor predisposisi adalah faktor yang mempermudah terbentuknya perilaku seseorang. Faktor ini mencakup dari faktor yang melekat pada diri seseorang. Contoh dari faktor predisposisi yaitu pengetahuan, sikap, kepercayaan yang dianut, tingkat pendidikan, dan tingkat ekonomi (Notoadmojo.2007).

\section{Identifikasi Pengetahuan}

Perolehan hasil wawancara mengenai tingkat pengetahuan operator kompresor ammonia dan urea sebagai berikut:

Pengukuran tingkat pengetahuan dari operator kompresor secara keseluruhan diperoleh hasil yang terbanyak pada kategori tingkat pengetahuan tinggi dengan persentase sebesar $88 \%$. Tingkat pengetahuan operator kompresor yang termasuk dalam kategori pengetahuan yang baik, jadi dapat disimpulkan bahwa tingkat pengetahuan termasuk dalam salah satu faktor pendorong perilaku patuh terhadap penggunaan APT.

Penelitian yang dilakukan oleh puspa Ningrum (2016) pada pekerja bagian tabung gas LPG dengan sampel sejumlah 51 orang. Hasil penelitian tersebut diperoleh bahwa ada hubungan antara pengetahuan dengan kepatuhan penggunaan APD. Penelitian tersebut sejalan dengan penelitian Susanto (2015) pada pekerja sandblasting di BSB
Tabel 3. Pengukuran Tingkat Pengetahuan

\begin{tabular}{ccc}
\hline No & $\begin{array}{c}\text { Kategori } \\
\text { Tingkat } \\
\text { Pengetahuan }\end{array}$ & $\begin{array}{c}\text { Hasil } \\
\text { Pengukuran }\end{array}$ \\
\hline 1 & Rendah & $0 \%$ \\
2 & Sedang & $8 \%$ \\
3 & Tinggi & $88 \%$ \\
4 & Sangat Tinggi & $5 \%$ \\
\hline
\end{tabular}

Gresik dengan populasi 11 orang pekerja. Hasil penelitian tersebut menjelaskan bahwa terdapat hubungan antara pengetahuan dengan kepatuhan penggunaan APD. Berdasarkan beberapa penelitian tersebut, maka dapat disimpulkan adanya hubungan antara pengetahuan dengan perilaku seseorang.

Pada deskripsi tingkat pengetahuan secara rinci akan dijelaskan menjadi dua bagian. Bagian tersebut yaitu pengetahuan tentang kebisingan dan pengetahuan tentang APT. Deskripsi tentang kedua pengetahuan tersebut sebagai berikut:

Hasil wawancara yang diperoleh, kebanyakan operator kompresor belum mengetahui tentang pengendalian teknik. Mereka kebanyakan mengetahui pengendalian secara administratif dan penggunaan APT. Hasil wawancara hanya $28 \%$ operator kompresor yang mengetahui pengendalian teknik. Hal tersebut terjadi karena operator kompresor tidak menyadari bahwa beberapa fasilitas yang terdapat pada area kerja termasuk pengendalian teknis, namun apabila peneliti menyebutkan contoh fasilitas yang termasuk pengendalian teknis mereka baru menyadari kalau fasilitas tersebut termasuk pengendalian teknis. Operator kompresor yang mengetahui pengendalian teknik menjawab bahwa pengendalian yang sudah dilakukan adalah pembuatan shelter dengan design yang dapat meredam suara. Mereka mengatakan shelter diberi pintu ganda atau karet supaya dapat meredam suara, selain itu mereka menjawab pengendalian teknik menggunakan peredam pada mesin dan pipa yang menjadi sumber kebisingan. Peredam tersebut biasa disebut silentser. Silentser tidak hanya berfungsi meredam kebisingan, tetapi juga digunakan untuk meredam panas yang ditimbulkan dari mesin. 
Tabel 4. Pengetahuan Tentang Kebisingan

\begin{tabular}{clcc}
\hline \multirow{2}{*}{ No Keterangan } & \multicolumn{2}{c}{ Jawaban } \\
\cline { 3 - 4 } & & Tahu & Tidak Tahu \\
\hline 1 & Pengendalian Kebisingan Secara Teknis & $28 \%$ & $72 \%$ \\
2 & Pengendalian Kebisingan Secara Administratif & $95 \%$ & $5 \%$ \\
3 & Pengendalian Dengan APT & $97 \%$ & $3 \%$ \\
4 & Dampak Kebisingan Langsung & $23 \%$ & $77 \%$ \\
5 & Dampak Kebisingan Tidak Langsung & $100 \%$ & $0 \%$ \\
6 & Pengukuran Kebisingan Dilakukan Secara Berkala & $82 \%$ & $18 \%$ \\
7 & Operator Melihat Petugas Hiperkes Melakukan Pengukuran & $85 \%$ & $15 \%$ \\
8 & Mengetahui Informasi Kebisingan Selain Dari Rambu & $41 \%$ & $59 \%$ \\
& Kebisingan & & \\
9 & Intensitas dan Durasi Kebisingan & $35 \%$ & $65 \%$ \\
10 & Dosis Paparan Kebisingan & $35 \%$ & $65 \%$ \\
\hline
\end{tabular}

Pengendalian administratif dan penggunaan APD sudah banyak diketahui oleh operator kompresor. Sebesar $60 \%$ mengetahui tentang pengendalian administrasi, namun ketika kami menanyakan tentang keberadaan rambu mereka mengetahui dan menyadari bahwa rambu termasuk pengendalian administratif. Jawaban operator kompresor mengenai pengendalian administratif yaitu adanya pelatihan, sosialisasi, dan Rambu. Sedangkan wawancara mengenai pengendalian APT mendapatkan hasil bahwa 100\% mengetahui bahwa terdapat 2 APT yaitu ear muff dan ear plug.

Data yang diperoleh hanya 23\% operator kompresor yang mengetahui dampak langsung dari kebisingan. Berdasarkan hasil wawancara yang dilakukan, operator kompresor tidak mengetahui dampak langsung dari kebisingan dikarenakan jarangnya sosialisasi mengenai kebisingan sebesar 72\%. Lupa terhadap hasil sosialisasi yang telah didapat dikarenakan terlalu banyak yang difikirkan sebesar $64 \%$ dan tidak pernah merasakan dampak langsung dari kebisingan sebesar $36 \%$. Hasil wawancara operator kompresor yang mengetahui dampak langsung kebisingan menyebutkan bahwa dampak langsung dari kebisingan adalah konsentrasi terganggu menjadi dampak langsung, selain itu mereka menjawab sulit berkomunikasi dan menguras tenaga. Dampak secara tidak langsung sebesar $100 \%$ operator kompresor telah mengetahuinya.

Sebagian besar operator kompresor mengetahui dan melihat petugas keselamatan dan kesehatan kerja saat melakukan pengukuran kebisingan. Hasil wawancara menunjukkan bahwa $85 \%$ mengetahui pengukuran kebisingan. Selain itu sebagian operator kompresor mengetahui pengukuran kebisingan dilakukan secara berkala. Sebanyak $82 \%$ operator kompresor mengetahui cek kebisingan dilakukan secara berkala.

Operator yang tidak mengetahui petugas $\mathrm{K} 3$ melakukan pengukuran kebisingan sejumlah $15 \%$ dan tidak mengetahui pengukuran kebisingan dilakukan secara berkala sejumlah $18 \%$. Sebagian operator tersebut tidak mengetahui dikarenakan terdapat 4 shift kerja pada operator kompresor. Sehingga operator yang mengetahui hanya operator kompresor yang bertugas saat dilakukan pengukuran oleh petugas $\mathrm{K} 3$.

Paparan kebisingan terdiri dari intensitas dan durasi paparan. Hasil wawancara yang dilakukan diperoleh bahwa sebagian besar tidak mengetahui paparan kebisingan. Operator yang tidak mengetahui paparan kebisingan sebesar $32 \%$. Pengetahuan tentang paparan kebisingan berbanding lurus dengan pengetahuan tentang intensitas dan durasi paparan kebisingan. Pengetahuan operator tentang intensitas dan durasi paparan hanya sebesar 35\%. Sebesar 92\% operator kompresor hanya mengetahui intensitas kebisingan dan sebesar $47 \%$ hanya mengetahui durasi paparan kebisingan. Kurangnya pengetahuan mengenai paparan kebisingan karena mereka lupa terhadap sosialisasi yang telah didapat. Hasil 
wawancara yang diperoleh, operator yang mengetahui intensitas, durasi maksimal dan paparan kebisingan menjawab bahwa mereka hanya paham namun tidak hafal batasan maksimalnya.

Tabel 5. Pengetahuan Tentang APT

\begin{tabular}{|c|c|c|c|}
\hline \multirow[b]{2}{*}{ No } & \multirow[b]{2}{*}{ Keterangan } & \multicolumn{2}{|c|}{ Jawaban } \\
\hline & & Tahu & $\begin{array}{l}\text { Tidak } \\
\text { Tahu }\end{array}$ \\
\hline 1 & Jenis APT & $100 \%$ & $0 \%$ \\
\hline 2 & $\begin{array}{l}\text { Kegunaan Pada } \\
\text { Kebisingan } \\
\text { Tertentu }\end{array}$ & $52,5 \%$ & $47,5 \%$ \\
\hline 3 & $\begin{array}{l}\text { Pengetahuan } \\
\text { APT yang Boleh } \\
\text { Diminta }\end{array}$ & $75 \%$ & $25 \%$ \\
\hline 4 & $\begin{array}{l}\text { Cara } \\
\text { Pengambilan } \\
\text { APT }\end{array}$ & $100 \%$ & $0 \%$ \\
\hline 5 & $\begin{array}{l}\text { Sosialisasi } \\
\text { dan Pelatihan } \\
\text { Tentang APT }\end{array}$ & $100 \%$ & $0 \%$ \\
\hline
\end{tabular}

Seluruh operator sudah mengetahui mengenai jenis, manfaat, dan kegunaan APT. Mereka mengetahuinya dikarenakan APT hanya terdiri dari 2 jenis yaitu ear plug dan ear muff. Sebesar 47,5\% operator kompresor tidak mengetahui tingkat perendaman atau pengurangan intensitas pada APT tertentu. Hal tersebut dikarenakan belum adanya sosialisasi tentang tingkat peredaman pada ear plug dan ear muff, namun mereka hanya mengetahui kedua APT yang dipakai pada tingkat intensitas tertentu sesuai dengan yang terdapat pada rambu. Keterangan pada rambu tentang penggunaan APT yaitu 85-95 dBA menggunakan ear plug dan ear muff untuk kebisingan lebih dari 95 dBA. Selain itu pengetahuan mengenai cara pemakaian seluruh operator kompresor sudah mengetahui cara pemakaiannya. Sebagian besar dari mereka mengetahui cara pemakaian dari pelatihan awal masuk kerja dan melihat pekerja senior nya. Hal tersebut mudah dipahami oleh operator kompresor dikarenakan cara pemakaian yang mudah dan tidak ribet.

Seluruh operator kompresor yang telah diwawancarai telah mengetahui mengenai sosialisasi yang telah dilakukan, namun sosialisasi dan pelatihan yang sudah berjalan tidak dikhususkan tentang APT.
Sosialisasi tersebut umumnya mengenai keseluruhan APD yang tersedia di PT. Pupuk Kalimantan Timur.

Seluruh operator kompresor menyampaikan bahwa sosialisasi dan pelatihan dilakukan saat mereka pertama masuk kerja, namun hanya sebagian kecil operator kompresor yang mengetahui bahwa ada penyegaran sosialisasi dan pelatihan yang dilakukan. Sebagian besar operator kompresor tidak mengetahui dikarenakan sistem kerja operator kompresor menggunakan shift, jadi hanya shift tertentu yang mengikuti sosialisasi dan pelatihan yang dilaksanakan.

Seluruh operator sudah mengetahui cara pengambilan APT yang berada di gudang penyimpanan APD. Beberapa operator kompresor mengambil sendiri APT di gudang penyimpanan APD. Beberapa operator lebih memilih mengambil APT dengan menitipkan kepada sekretaris departemen operasi atau pekerja lain. Dari operator yang menitipkan pengambilan APT, mereka lebih senang pengambilan APT dengan dititipkan. Gudang penyimpanan tersebut yang mengelola adalah pihak departemen Keselamatan dan Kesehatan Kerja.

Sebesar 75\% operator kompresor hanya mengetahui pengambilan APD hanya yang diberikan saat awal masuk kerja seperti sepatu, helm, kacamata, dan ear plug. Sebesar 25\% operator kompresor kurang mengetahui bahwa boleh meminta APD selain yang didapat pada pertama masuk kerja. APD tersebut yaitu ear muff, gas mask, dll. Sebagian operator kompresor tidak mengetahui kalau boleh meminta ear muff mereka kebanyakan beli sendiri. Hal tersebut terjadi karena sosialisasi yang didapat operator kompresor hanya pada saat pelatihan saja dan operator kompresor yang junior mengetahui operator senior yang kebanyakan membeli ear muff sendiri.

\section{Identifikasi komitmen}

Hasil wawancara yang dilakukan, seluruh operator memiliki komitmen untuk menggunakan APT bukan karena terikat dengan peraturan yang terdapat pada PT. Pupuk Kalimantan Timur. Sebesar $80 \%$ operator kompresor berkomitmen menggunakan APT dikarenakan sadar 
akan kesehatan telinga, sebesar 68\% operator kompresor menggunakan APT atas dasar merasa terganggu apabila tidak menggunakan APT di area kompresor.

Penelitian yang dilakukan oleh puspa Ningrum (2016) pada pekerja bagian tabung gas LPG dengan sampel sejumlah 51 orang. Hasil penelitian tersebut diperoleh hasil bahwa ada hubungan antara motivasi atau komitmen dengan kepatuhan penggunaan APD. Penelitian tersebut sejalan dengan penelitian Susanto (2015) pada pekerja sandblasting di BSB Gresik dengan populasi 11 orang pekerja. Hasil penelitian tersebut menjelaskan bahwa terdapat hubungan antara motivasi atau komitmen dengan kepatuhan penggunaan APD. Beberapa penelitian yang telah dilakukan, motivasi atau komitmen dapat menjadi faktor pendorong terhadap perilaku seseorang.

\section{Faktor Penguat (Reinforcing Factor)}

Faktor penguat yaitu faktor yang mendorong atau memperkuat terjadinya perilaku seseorang. Faktor ini mencakup bantuan dari pihak lain dan peraturan yang berlaku. Contoh faktor penguat yaitu peraturan pemerintah, sikap, dan perilaku tokoh masyarakat atau petugas yang berpengaruh dan lainnya (Notoadmojo, 2007).

\section{Pengawasan APD}

Tidak ada pengawasan kualitas APD secara khusus yang dilakukan oleh petugas bagian pengadaan K3. Pengawasan APD dilakukan oleh individu pekerja masingmasing. Pengawasan APT yang dilakukan oleh petugas bagian pengadaan hanya bersifat pasif. Mereka melihat APT yang sudah rusak atau hilang dengan melihat laporan pengambilan APD. Pada saat pengambilan APD pekerja harus membawa APD yang rusak. Hal tersebut dilakukan apabila waktu antara pengambilan yang terdahulu dengan saat ini jangka waktunya terlalu pendek. Apabila jangka waktu lama, pekerja boleh meminta APD tanpa memperlihatkan APD yang rusak.

Pengawasan juga dilakukan dengan menggunakan lembar kuesioner. Kuesioner tersebut dibagikan kepada pekerja yang memiliki APD yang mudah rusak. Kuesioner tersebut diberikan pada saat pekerja meminta kembali APD. Hasil kuesioner tersebut akan dianalisis penyebabnya dan dilakukan tindakan perbaikan. Hasil wawancara dulu pernah terdapat ear muff dengan merek tertentu yang mudah rusak, lalu pihak pengadaan mengganti earmuff dengan merek lain yang lebih bertahan lama. Saat pengawasan dilakukan dengan melihat komplain dari pekerja. Beberapa pekerja komplain tentang kenyamanan pemakaian APD dan ketahanan APD yang telah dibagikan oleh bagian pengadaan K3.

Pengawasan yang dilakukan oleh petugas pengadaan APD bersifat pasif, jadi dapat dimungkinkan bahwa pengawasan tentang APT bukan termasuk faktor pendorong perilaku patuh terhadap penggunaan APT. Hal tersebut sejalan dengan penelitian yang dilakukan oleh Susanto (2015). Penelitian tersebut menjelaskan bahwa terdapat hubungan yang sangat lemah antara pengawasan dengan kepatuhan menggunakan APD.

\section{Perawatan APD}

Tidak ada perawatan kualitas APD secara khusus yang dilakukan oleh petugas bagian pengadaan K3. Perawatan APD dilakukan oleh individu pekerja masing-masing. Petugas bagian pengadaan departemen K3 hanya melakukan perawatan dari kualitas yang disediakan. Mereka memperbaiki atau mengganti merek APD yang lebih baik, sehingga masa pakai lebih lama dari pada APD lain. Pembelian APT juga harus sesuai standar supaya menjamin kualitas dan keamanan suatu APT.

Perawatan yang dilakukan oleh petugas pengadaan APD bersifat pasif, jadi dapat disimpulkan bahwa kemungkinan perawatan APT bukan termasuk faktor pendorong perilaku patuh terhadap penggunaan APT.

\section{Pengawasan Pemakaian APT}

Pengawasan pemakaian APD belum dilakukan oleh petugas pengadaan APD. Pengawasan tersebut tidak dilakukan karena ketersediaan sumber daya manusia yang sedikit dan pekerjaan yang banyak. Pengawasan penggunaan APT dilakukan oleh inspector K3 karena inspector K3 lebih 
sering di lapangan, jadi pada saat sidak pihak inspektor juga melihat kualitas APD dan pematuhan pemakaiannya.

Pengawasan pemakaian APT telah dilakukan dengan baik oleh inspektor K3, jadi dapat disimpulkan bahwa pengawasan pemakaian APT termasuk salah satu faktor pendorong perilaku patuh terhadap penggunaan APT. Hal tersebut sejalan dengan penelitian yang dilakukan oleh Sudarmo (2015) pada perawat bedah di Instalasi Bedah Sentral RSUD Ulin Banjarmasin dengan sampel sejumlah 81 pekerja. Penelitian tersebut menerangkan bahwa pengawasan pemakaian APT mempengaruhi perilaku penggunaan APD.

\section{Sosialisasi dan Pelatihan Mengenai APT}

Sosialisasi dan pelatihan mengenai APT pada saat pekerja pertama masuk kerja, namun pada saat pertama masuk kerja belum terdapat sosialisasi mengenai cara pengambilan APT dan belum ada sosialisasi mengenai APT yang boleh diminta dengan persyaratan tertentu. Contoh misalkan pengambilan ear muff diperbolehkan pada pekerja yang area kerjanya terdapat kebisingan diatas $95 \mathrm{dBA}$. Sosialisasi dan pelatihan APT dilakukan pada departemen masing-masing, namun sosialisasi tersebut bersifat pasif. Hal tersebut karena dilaksanakan atas dasar permintaan dari departemen yang membutuhkan sosialisasi tersebut. Tidak ada agenda khusus dalam sosialisasi dan pelatihan mengenai APT yang terdapat yaitu agenda sosialisasi dan pelatihan pemakaian breathing aparatus yang dilakukan setiap tahun.

Sosialisasi yang dilakukan oleh petugas pengadaan APD yaitu bersifat pasif, jadi dapat disimpulkan bahwa pelatihan dan sosialisasi bukan salah satu faktor pendorong perilaku penggunaan APT. Hal tersebut sejalan dengan penelitian yang dilakukan oleh putri (2014) pada pekerja unit produksi alumunium sulfat PT. Liku Telaga Gresik dengan total populasi sebesar 114 tenaga kerja. Penelitian tersebut diperoleh hasil bahwa tidak ada hubungan antara pelatihan dengan kepatuhan penggunaan APD. Selain itu penelitian yang dilakukan oleh Puspaningrum (2016) juga menjelaskan bahwa tidak ada hubungan antara pelatihan dengan kepatuhan penggunaan APT.

\section{Pengukuran Kebisingan}

Pengukuran kebisingan dilakukan secara berkala. Pengukuran dilakukan selama satu bulan sekali. Pada saat pengukuran, petugas langsung mengukur pada titik pengukuran. Saat petugas melakukan pengukuran tidak izin kepada operator terkait, sehingga sebagian operator tidak mengetahui bahwa kebisingan diukur secara berkala. Pengukuran kebisingan dilakukan dengan menggunakan sound level meter. Hasil pengukuran kebisingan mendapatkan hasil bahwa di area kompresor seluruh pabrik memiliki tingkat kebisingan melebihi 95 $\mathrm{dBA}$. Tingkat kebisingan paling tinggi pada area kompresor di pabrik 2 Urea dengan tingkat kebisingan 113 dBA. Pengukuran dilakukan pada pagi hari. Pengukuran dimulai 09.00- selesai.

\section{Evaluasi Hasil Pengukuran Kebisingan}

Hasil pengukuran yang dilakukan oleh petugas K3 secara berkala hanya sebagai bahan evaluasi. Laporan hasil pengukuran disampaikan oleh operator. Informasi tersebut langsung disampaikan secara lisan pada saat pengukuran sedangkan hasil pengukuran tidak dilaporkan secara tertulis kepada departemen terkait, sehingga sebesar 59\% operator kompresor tidak mengetahui informasi kebisingan selain informasi dari rambu kebisingan.

Apabila hasil pengukuran ada kenaikan kebisingan, maka petugas $\mathrm{K} 3$ memberikan rekomendasi pengendalian kepada departemen terkait. Misalnya pengendalian secara teknik, maka petugas $\mathrm{K} 3$ memberikan rekomendasi kepada departemen maintenance. Pihak maintenance yang bertanggung jawab atas pengendalian tersebut seperti pemberian peredam pada kompresor dan perbaikan tempat istirahat sementara.

Laporan hasil pengukuran dijadikan sebagai bahan untuk pengendalian secara administratif dan penerapan APT oleh pihak K3. Pengendalian administratif yang dilakukan diantaranya memasang rambu kebisingan dan instruksi pemakaian APT. Selain itu pengendalian administratif 
dengan pembuatan denah kebisingan di setiap pabrik.

\section{Peraturan Pemerintah}

Peraturan Menteri Tenaga Kerja dan Transmigrasi No. 08 tahun 2010 tentang APD. Peraturan tersebut berisi tentang kewajiban pengusaha atau pemberi kerja dalam memenuhi dan mengelola APD. Kewajiban tersebut antara lain:

a) Menyediakan APD

b) APD diberikan secara Cuma - cuma

c) APD harus sesuai dengan SNI.

d) Petugas wajib menggunakan APD saat pengawasan

e) Mengumumkan secara tertulis dan memasang rambu

f) Wajib melaksanakan manajemen APD

g) Identifikasi kebutuhan dan sarat APD

h) Pemilihan APD yang sesuai

i) Pelatihan

j) Penggunaan, perawatan, dan penyimpanan

k) Pembinaan

l) Inspeksi

m) Evaluasi dan pelaporan

n) Pengolahan APD yang rusak

Peraturan tersebut mengatur kewajiban dan hak pekerja yaitu Pekerja dan buruh diwajibkan memakai APD dan Pekerja berhak menyatakan keberatan untuk melakukan pekerjaan apabila APD tidak sesuai. Isi dari kedua peraturan tersebut belum menjelaskan secara rinci mengenai kebisingan dan penggunaan APT, namun kedua peraturan ini bisa dijadikan acuan dasar atau acuan dalam melakukan pengendalian dan pembuatan program tentang perilaku dan kepatuhan menggunakan APT terhadap dampak kebisingan.

\section{Peraturan Kebijakan}

PT Pupuk Kalimantan Timur mempunyai kebijakan dan peraturan tentang kebisingan dan APD diantaranya:

a. Kebijakan tentang Keselamatan dan Kesehatan Kerja yang menjelaskan komitmen PT. Pupuk Kalimantan Timur menerapkan Manajemen Keselamatan dan Kesehatan Kerja.

b. Surat keputusan Direksi Nomor 6 tahun 2012 tentang Peraturan Umum Keselamatan Dan Kesehatan Kerja. Surat keputusan tersebut berisi tentang setiap calon Karyawan Perusahaan yang akan dipekerjakan harus diyakinkan telah mendapat bekal tentang petunjuk dan peraturan-peraturan K3 melalui Pelatihan Dasar K3 yang diselenggarakan oleh Perusahaan dan karyawan wajib mengikutinya. Setiap Pekerja yang akan bekerja di zona Tertutup, zona Khusus, dan zona Terlarang harus mendapatkan bekal K3 melalui pengarahan atau induksi K3 yang diselenggarakan oleh perusahaan. Peraturan tersebut terdapat aturan yang mengatur tentang rambu yang terdapat pada area pabrik. Berdasarkan peraturan tersebut, pekerja Dilarang memindahkan atau mengubah poster K3, rambu K3, kotak saran, papan pengumuman, dan sarana komunikasi K3 yang ada di lingkungan perusahaan kecuali atas persetujuan Departemen K3.

C. Prosedur mendapatkan dan penggantian APD. Berdasarkan prosedur ini, semua pekerja di lingkungan operasi/pabrik wajib menggunakan APD yaitu: sepatu safety, safety had, ear plug, dan kaca mata. Pengawasan kualitas dan kebutuhan APD dilakukan oleh kepala unit kerja dengan menandatangani MIR. Pencatatan dan pengadaan APD dilakukan oleh departemen K3.

Menurut peraturan diatas, belum terdapat peraturan yang menjelaskan tentang pengendalian kebisingan dan kepatuhan menggunakan APD. Namun dalam Surat Keputusan Direksi no 06 tahun 2012 menjelaskan bahwa karyawan wajib mengikuti sosialisasi dan pelatihan K3 saat awal masuk kerja dan agenda lainnya. Peraturan tersebut juga menjelaskan bahwa karyawan yang masuk ke area pabrik wajib menggunakan APD. Selain itu karyawan dilarang memindah dan merusak rambu serta sarana informasi K3.

Peraturan Pemerintah dan Peraturan Perusahaan menjelaskan bahwa pekerja wajib menggunakan APT, jadi dapat disimpulkan bahwa peraturan merupakan salah satu faktor pendorong perilaku penggunaan APT. Hal tersebut sejalan dengan penelitian yang dilakukan oleh putri (2014) menjelaskan bahwa adanya hubungan antara sikap terhadap kebijakan dengan kepatuhan menggunakan APD. 


\section{Faktor Pemungkin (Enabling Factor)}

Faktor pemungkin adalah faktor yang memfasilitasi perilaku atau tindakan seseorang. Faktor ini mencakup fasilitas yang dapat mendukung terbentuknya perilaku. Contoh faktor pemungkin yaitu ketersediaan sarana dan prasarana seperti peralatan, tempat, transportasi dan lainnya (Notoadmojo.2007).

\section{Penyediaan APD}

Penyediaan APT dilakukan oleh Departemen Keselamatan dan Kesehatan Kerja pada bagian Binaper. APT yang tersedia adalah ear plug dan ear muff. Penyediaan APT mereka memesan dan membeli APT kepada penyedia jasa penjualan APT, setelah memesan beberapa lama sampai APT akan dikirim.

Pada saat pertama masuk kerja semua pekerja pabrik akan diberikan APD yang diwajibkan untuk memasukan area pekerjaan seperti sepatu, helm, dan ear plug pada area operasi. Persediaan ear plug untuk pekerja dibagikan ke seluruh pekerja yang terpapar bising lebih $85 \mathrm{dBA}$. Ear plug dibagikan pada masing-masing individu dengan jumlah 1 ear plug untuk 1 pekerja. Hal tersebut dikarenakan agar pekerja tidak terlalu ceroboh dalam menyimpan. Karena apabila diberikan banyak maka kurang efisien dalam hal keuangan. Jenis ear plug yang dibagikan secara personal terbuat dari karet dan dapat dipakai berulang. Jadi masih aman apabila digunakan dalam waktu yang cukup lama dan dapat menghemat anggaran.

Menurut pengalaman petugas pengadaan, Jangka waktu masa pakai ear plug jenis karet rata-rata 6 bulan. Mereka harus meminta ear plug apabila belum mempunyai ear plug atau ear plugnya sudah rusak di bagian pergudangan departemen $\mathrm{K} 3$, namun pihak pengadaan departemen K3 tidak membatasi waktu pengambilan ear plug. Pekerja boleh meminta lagi ear plug setiap saat asalkan ear plug sudah rusak atau tidak layak pakai.

Persediaan ear plug juga dibagikan ke setiap departemen sebagai barang inventaris departemen. Ear plug yang dibagikan pada departemen sejumlah 1 pack atau kotak yang berisi 100 pasang ear plug. Persediaan tersebut ditunjukkan sebagai persediaan ketika operator kompresor lupa membawa ear plug. Selain itu ketika ear plug pekerja operasi rusak, pekerja operasi bisa memakai ear plug tersebut dipakai atau mungkin pekerja meminta lagi ke bagian pengadaan departemen K3. Apabila ear plug yang sudah disediakan habis, maka pihak departemen boleh meminta kembali ke bagian pengadaan. Tidak ada jangka waktu minimal untuk mengambil ear plug kembali asalkan jangka waktu pengambilan kembali tidak terlalu cepat, namun realitanya ada beberapa departemen yang tidak meminta. Hal tersebut terjadi dimungkinkan karena pihak departemen yang tidak meminta sudah menyediakan sendiri ear plug atau mereka malas ke bagian pengadaan.

Tidak hanya ear plug yang dibagikan ke setiap departemen. Melainkan ear muff juga dibagikan ke setiap departemen. Ear muff yang di sediakan di setiap departemen digunakan sebagai barang inventaris apabila ada pekerja yang akan bekerja dalam tingkat kebisingan diatas 95dbA dapat memakai ear muff tersebut. Ear muff tersebut dapat digunakan bagi pekerja yang hanya sementara bekerja pada area dengan kebisingan diatas 95dbA. Apabila pekerja bekerja di area dengan kebisingan diatas $95 \mathrm{dbA}$ setiap hari, maka pekerja tersebut wajib meminta ear plug ke bagian pengadaan departemen $\mathrm{K} 3$. Persediaan ear muff hanya ditunjukkan pada pekerja yang terpapar kebisingan diatas $95 \mathrm{dBA}$. Apabila area kerja kurang dari $95 \mathrm{dBA}$, maka pekerja tidak diperbolehkan meminta APT tersebut. Hal tersebut bertujuan untuk menghemat pengeluaran untuk pembelian ear muff.

Penyediaan APT yang telah dilakukan oleh petugas sudah dalam kategori baik, jadi dapat disimpulkan bahwa penyediaan termasuk dalam salah satu faktor pendorong perilaku penggunaan APD. Hal tersebut sejalan dengan penelitian yang dilakukan oleh Sudarmo (2015) menjelaskan bahwa penyediaan APD berpengaruh terhadap kepatuhan penggunaan APD.

\section{Rambu Kebisingan}

Hasil wawancara dan observasi menjelaskan bahwa seluruh area pabrik sudah dilengkapi dengan rambu kebisingan. Rambu kebisingan tersebut berisi tenang 
besar intensitas kebisingan pada area tersebut. Rambu kebisingan tersebut juga berisi saran APT yang minimal yang digunakan pada area tersebut. Selain itu dalam pabrik juga dilengkapi dengan denah kebisingan yang bertujuan untuk mengetahui area dengan intensitas tertentu.

Penyediaan Rambu kebisingan sudah masuk dalam kategori baik yaitu terbukti dengan terdapat rambu kebisingan di seluruh pabrik, jadi dapat disimpulkan adanya rambu kebisingan menjadi salah satu faktor pendorong perilaku penggunaan APT.

\section{SIMPULAN}

Seluruh operator kompresor ammonia dan urea PT. Pupuk Kalimantan Timur sudah patuh dalam menggunakan APT. Namun masih terdapat beberapa faktor pendorong perilaku patuh terkait penggunaan APT yang belum sesuai. Faktor pendorong tersebut yaitu pengetahuan operator kompresor tentang pengendalian kebisingan secara teknik, dampak langsung dari kebisingan, intensitas dan durasi paparan yang sesuai.

\section{DAFTAR PUSTAKA}

Handayani dkk.2008. Hubungan antara penggunaan APD dengan, umur dan masa kerja dengan kecelakaan kerja pada pekerja rustic di PT Borneo melintang buana export Yogyakarta. Yogyakarta.

Notoatmodjo S. 2007. Pendidikan dan perilaku kesehatan. Jakarta: Rineka Cipta.

Peraturan menteri tenaga kerja dan transmigrasi no 8. Tahun 2010 tentang APD.

Prakoso, Gilang. Fatah. 2017. Analysis of Effect Attitude, Perceived, And Subjective Norm on Safety Behavior. Jurnal Promkes Vol. 5 No. 2 Desember 2017: 193 - 204.
Puspitaningrum. 2016. Analisis Faktor Yang Mempengaruhi Tingkat Kepatuhan Penggunaan APD (APD) Pada Pekerja Bagian Tabung Gas Liquified Petroleum Gas (LPG). Fakultas Kesehatan Masyarakat, Universitas Hasanudin Makassar.

Putri, Kartika. 2014. Analisis Faktor Yang Berhubungan Dengan Kepatuhan Menggunakan APD. Gresik. Universitas Airlangga.

Rahmawati. 2015. Faktor-Faktor Yang Berhubungan Dengan Gangguan Pendengaran Pada Pekerja Metal Forming dan Heat Treatment. Jakarta. Universitas Islam Negeri Syarif Hidayatullah Jakarta.

Setyanto.dkk.2011. Pengaruh Lingkungan Fisik Kerja Terhadap Waktu Penyelesaian Pekerjaan. Di Pt Putra Karangetang Popontolen.

Sudarmo.dkk.2015. Faktor Yang Mempengaruhi Perilaku Terhadap Kepatuhan Penggunaan APD (APD) Untuk Pencegahan Penyakit Akibat Kerja. Banjarmasin. Universitas Mulawarman.

Suma'mur P. 2009. Hiegiene Perusahaan dan Kesehatan Kerja. Jakarta: Gunung Agung.

Surat keputusan Direksi PT. Pupuk Kalimantan Timur Nomor 6 tahun 2012 tentang peraturan umum keselamatan dan kesehatan kerja.

Susanto, Aditya. 2016. Hubungan Faktor predisposing, Reinforcing dan Enabling dengan Perilaku Pemakaian APD pada Pekerja Sandblasting di PT BSB, Gresik. Universitas Airlangga Surabaya.

Tarwaka, Bakri. Sudiajeng, L. 2004. Ergonomi untuk Keselamatan, Kesehatan Kerja dan Produktivitas. Surakarta: UNIBA PRESS.

Tjan. 2013. Efek Bising Elektronika Terhadap Gangguan Fungsi Pendengaran Pad Pekerja Di Kecamatan Sario Kota Manado. Manado. 